\title{
Effect of the addition of bird repellents to aerially applied 1080 baits on rat and possum abundance
}

\author{
Michelle Crowell $^{1 *}$, Mark Martini ${ }^{2}$ and Elena Moltchanova ${ }^{3}$ \\ ${ }^{1}$ Science and Policy Group, Department of Conservation, Private Bag 4715, Christchurch 8041 \\ ${ }^{2}$ Department of Conservation, Hokitika Office, Private Bag 701, Hokitika 7842 \\ ${ }^{3}$ Department of Mathematics and Statistics, University of Canterbury, Private Bag 4800, Christchurch 8140 \\ *Author for correspondence: (Email: mcrowell@doc.govt.nz)
}

Published online: 9 September 2015

\begin{abstract}
One of the criteria for an effective bird repellent in a pest management context in New Zealand is that possum (Trichosurus vulpecula) and ship rat (Rattus rattus) kills remain high where repellents are used in poison baits. Repellents were used in baits applied within different treatment blocks as part of a large aerial 1080 operation in November 2013 near Haast on the West Coast of the South Island of New Zealand. We compared the proportional reduction in possum and rat population indices between standard aerial 1080 treatment, primary repellent treatment $(0.17 \% \mathrm{wt} / \mathrm{wt} \mathrm{d}$-pulegone in prefeed and $1080 \mathrm{baits})$, and combined repellent treatment $(0.17 \% \mathrm{wt} / \mathrm{wt} \mathrm{d}$-pulegone and $0.10 \% \mathrm{wt} / \mathrm{wt}$ anthraquinone in prefeed and $0.17 \% \mathrm{wt} / \mathrm{wt}$ d-pulegone in 1080 baits). All three treatments reduced the post-operational tracking rate of relative abundance for rats compared with the pre-operational rate. The standard treatment (100\% proportional reduction in both blocks) was more effective than either repellent treatment, although the small difference between standard and primary $(100 \%$ and $96 \%$ proportional reduction in two blocks) may not be meaningful, given the coarseness of the rat tracking index. The combined repellent treatment was the least effective ( $78 \%$ and $89 \%$ proportional reduction in the two blocks), with post-operational tracking indices of $3 \% \pm 2$ (standard error) and $8 \% \pm 6$. There was no difference in the three-night Bite Mark Index for possums between treatments. The results indicate that both repellent treatments could be used for possum control; however, the combined repellent treatment did not control rats to $<5 \%$ tracking index, a level considered sufficient to protect native animals from rat predation. The primary repellent treatment reduced both possum and rat population indices satisfactorily, indicating it could be a useful bird repellent candidate if d-pulegone can be stabilised in cereal baits.
\end{abstract}

Keywords: anthraquinone; d-pulegone; kea; Nestor notabilis; New Zealand; non-target risk; pest control; Rattus rattus; Trichosurus vulpecula

\section{Introduction}

Introduced mammal pests are controlled in New Zealand to protect biodiversity and agricultural values, including through the aerial application of 1080 (sodium fluoroacetate) cereal baits (Parkes \& Murphy 2003). Birds that may be poisoned in these operations include kea (Nestor notabilis), an endemic mountain parrot (Veltman \& Westbrooke 2011). Standards are in place to reduce the risk to kea from aerial 1080 on land managed by the Department of Conservation (DOC) and these are regularly reviewed to keep pace with kea-related research (DOC 2014).

A series of trials began in 2009 to develop an effective bird repellent to prevent kea deaths in aerial 1080 cereal operations (Orr-Walker et al.2012; Cowan et al. 2014; Crowell et al. 2015; van Klink \& Crowell 2015). One of the criteria for an effective bird repellent in this context is that possum (Trichosurus vulpecula) and ship rat (Rattus rattus) kills remain high where repellents are used. Otherwise, reduced pest mortality could compromise the conservation benefits of aerial 1080 operations. The repellents under investigation are d-pulegone and 9,10-anthraquinone ('anthraquinone'), as recommended by Spurr (2008) in a review for the Kea Conservation Trust. There is evidence that birds in New Zealand have been repelled when a range of bait types have been treated with d-pulegone and anthraquinone (sometimes in combination with other additives), including kea(Orr-Walker etal.2012), North Island robins (Petroica australis; Day et al. 2003; Clapperton et al. 2014), tomtits (Petroica macrocephala toitoi; Clapperton et al. 2014), and house sparrows (Passer domesticus; Clapperton et al. 2012; Day et al. 2012). Crowell et al. (2015) provide more detail on d-pulegone and anthraquinone as bird repellents.

At the time when this combination was selected, there was limited information on palatability and efficacy for possums and rodents (Day et al. 2000). Since then a number of pen and field trials have been published, as summarised in Table 1 . Most of the literature on pest response is New Zealand-based, where the main application is the prevention of bird poisoning where toxic baits are used for pest control. In other countries, bird repellents are developed primarily for crop protection (Werner et al. 2011a) or for use on turf and around critical infrastructure (Clark \& Avery 2013), where pest efficacy is less relevant.

When rats were tested, most pen trials noted reduced palatability of prefeed baits when the anthraquinone concentration was $0.04 \% \mathrm{wt} / \mathrm{wt}$ or higher (Cowan et al. 2014; Clapperton etal.2015), with or without up to $0.26 \%$ d-pulegone. The mortality rates between repellent and non-repellent 1080 treatments in the pen trials involving anthraquinone were mixed (Table 1). Observations of other rodent species (black-tailed prairie dogs, Cynomys ludovicianus) suggest that anthraquinone repellency may not be dose-dependent (Werner 
Table 1. Summary of previous pen and field trials assessing palatability, mortality or monitoring results for possums, rats or other rodents, where d-pulegone or anthraquinone were used. For bait types, 'ST' indicates baits were surface-treated with repellents and 'IN' indicates repellents were incorporated into baits at manufacture. Baits were non-toxic except where a 1080 concentration is specified. All repellent and 1080 concentrations are nominal levels (i.e. as specified in the batch order and not necessarily verified after manufacture). Where more than one anthraquinone and d-pulegone concentration is reported in a single row, these are trial treatments that gave similar results. Some of the Clapperton et al. (2015) treatments also included other additives.

\begin{tabular}{|c|c|c|c|c|c|}
\hline Author & $\begin{array}{l}\text { Trial type, } \\
\text { year }\end{array}$ & Bait type & $\begin{array}{l}\text { Anthra- } \\
\text { quinone } \\
(\% \mathrm{wt} / \mathrm{wt})\end{array}$ & $\begin{array}{l}\text { D-pulegone } \\
(\% \mathrm{wt} / \mathrm{wt})\end{array}$ & Summary of results \\
\hline \multicolumn{6}{|l|}{ Wild rats } \\
\hline $\begin{array}{l}\text { Day et al. } \\
2000\end{array}$ & $\begin{array}{l}\text { Field, } \\
2000\end{array}$ & ST carrot & $\leq 0.10$ & $\leq 0.17$ & $\begin{array}{l}\text { No significant difference in bait take on first exposure or on } \\
\text { subsequent nights, as compared with untreated baits. }\end{array}$ \\
\hline $\begin{array}{l}\text { J Kemp } \\
\text { DOC, } \\
\text { pers. comm. }\end{array}$ & $\begin{array}{l}\text { Field, } \\
2010\end{array}$ & $\begin{array}{l}\text { IN cereal, } \\
\text { then IN } \\
0.15 \% \\
1080 \text { cereal }\end{array}$ & $\begin{array}{l}0 \\
0.10\end{array}$ & $\begin{array}{l}0 \text { or } 0.17 \\
\text { (prefeed) } \\
0.17 \text { (toxic) } \\
0.17 \text { (prefeed) } \\
0.17 \text { (toxic) }\end{array}$ & $\begin{array}{l}\text { No significant difference in the estimated reduction of rat } \\
\text { tracking index between repellent treatments and the standard } \\
\text { treatment. The treatment containing anthraquinone had a } \\
\text { relatively low percentage reduction of rats. }\end{array}$ \\
\hline \multicolumn{6}{|c|}{ Wild-caught ship rats (Rattus rattus) } \\
\hline $\begin{array}{l}\text { Clapperton } \\
\text { et al. } 2015\end{array}$ & $\begin{array}{l}\text { Pen, } \\
2002-2004 \\
\text { trial } 3\end{array}$ & $\begin{array}{l}\text { ST carrot, } \\
\text { then ST } \\
0.15 \% 1080 \\
\text { carrot }\end{array}$ & $\begin{array}{l}0.04 \\
0.04 \\
0.08\end{array}$ & $\begin{array}{l}0 \\
0.04 \\
0\end{array}$ & $\begin{array}{l}\text { Repellent baits were as palatable as standard baits. Mortality } \\
\text { rates did not differ between repellent and standard baits. }\end{array}$ \\
\hline $\begin{array}{l}\text { Cowan et al. } \\
2014\end{array}$ & Pen, 2013 & $\begin{array}{l}\text { IN cereal } \\
\text { then IN } \\
0.15 \% 1080 \\
\text { cereal }\end{array}$ & 0 & 0.17 & $\begin{array}{l}\text { No significant difference in palatability of prefeed baits or } \\
\text { mortality rates between this repellent treatment and the non- } \\
\text { repellent treatment. }\end{array}$ \\
\hline $\begin{array}{l}\text { Cowan et al. } \\
2014\end{array}$ & Pen, 2013 & $\begin{array}{l}\text { IN cereal } \\
\text { then IN } \\
0.15 \% 1080 \\
\text { cereal }\end{array}$ & $\begin{array}{l}0.10 \\
0.25 \\
0.25 \\
0.25 \\
\text { (prefeed } \\
\text { and toxic) }\end{array}$ & $\begin{array}{l}0.17 \\
0.17 \\
0 \\
0 \\
\text { (prefeed) } \\
0.17 \text { (toxic) }\end{array}$ & $\begin{array}{l}\text { Palatability of prefeed baits was lower and the amount of toxic } \\
\text { bait eaten was lower, as compared to the d-pulegone only and the } \\
\text { non-repellent treatment. These four treatments had the } \\
\text { significantly lower mortality rates as compared to the d-pulegone } \\
\text { only and the non-repellent treatment. }\end{array}$ \\
\hline \multicolumn{6}{|c|}{ Laboratory rats (Rattus norvegicus) } \\
\hline $\begin{array}{l}\text { Clapperton } \\
\text { et al. } 2015\end{array}$ & Pen, 1999 & ST carrot & $\begin{array}{l}0 \\
0.04\end{array}$ & $\begin{array}{l}0.17 \\
0.09\end{array}$ & Repellent baits were as palatable as non-repellent baits. \\
\hline $\begin{array}{l}\text { Clapperton } \\
\text { et al. } 2015\end{array}$ & Pen, 1999 & As above & $\begin{array}{l}0.08 \\
0.08 \\
0.12\end{array}$ & $\begin{array}{l}0 \\
0.17 \\
0.26\end{array}$ & $\begin{array}{l}\text { Repellent baits were less palatable than non-repellent baits and } \\
\text { no more palatable than salt-treated baits. }\end{array}$ \\
\hline $\begin{array}{l}\text { Clapperton } \\
\text { et al. } 2015\end{array}$ & $\begin{array}{l}\text { Pen, } \\
2002-2004 \\
\text { trial } 1\end{array}$ & $\begin{array}{l}\text { ST carrot, } \\
\text { then ST } \\
0.15 \% 1080 \\
\text { carrot }\end{array}$ & $\begin{array}{l}0.04 \\
\leq 0.08\end{array}$ & $\begin{array}{l}0.04 \\
0\end{array}$ & $\begin{array}{l}\text { Consumption of non-toxic repellent baits was less than for non- } \\
\text { repellent baits. Mortality rates did not differ between repellent } \\
\text { and standard baits. }\end{array}$ \\
\hline $\begin{array}{l}\text { Clapperton } \\
\text { et al. } 2015\end{array}$ & $\begin{array}{l}\text { Pen, } \\
2002-2004 \\
\text { trial } 2\end{array}$ & $\begin{array}{l}\text { ST carrot, } \\
\text { then ST } \\
0.08 \% 1080 \\
\text { carrot }\end{array}$ & $\begin{array}{l}0.04 \\
0.04 \\
0.04\end{array}$ & $\begin{array}{l}0 \\
0.0009 \\
0.04\end{array}$ & $\begin{array}{l}\text { Consumption of non-toxic repellent baits was less than for non- } \\
\text { repellent baits. Mortality rates were significantly lower in all } \\
\text { repellent treatments as compared to non-repellent baits. No } \\
\text { repellent treatment achieved a mortality rate of }>20 \% \text {. }\end{array}$ \\
\hline \multicolumn{6}{|c|}{ Black-tailed prairie dogs (Cynomys ludovicianus) } \\
\hline $\begin{array}{l}\text { Werner } \\
\text { et al. } 2011 b\end{array}$ & Pen, 2010 & $\begin{array}{l}\text { ST corn } \\
\text { seeds }\end{array}$ & $0.5-4$ & 0 & $\begin{array}{l}24-37 \% \text { repellency was observed in a concentration-response } \\
\text { test. Repellency was not directly related to anthraquinone } \\
\text { concentration. }\end{array}$ \\
\hline \multicolumn{6}{|l|}{ Possums } \\
\hline $\begin{array}{l}\text { Day et al. } \\
2000 \text {, } \\
\text { Clapperton } \\
\text { et al. } 2015\end{array}$ & Field, 2000 & ST carrot & $\leq 0.10$ & $\leq 0.17$ & $\begin{array}{l}\text { No significant difference in bait station disturbance or bait take, } \\
\text { as compared with non-repellent baits. }\end{array}$ \\
\hline $\begin{array}{l}\text { Clapperton } \\
\text { et al. } 2015\end{array}$ & $\begin{array}{l}\text { Pen, } \\
2002-2004 \\
\text { trial } 4\end{array}$ & $\begin{array}{l}\text { ST carrot, } \\
\text { then ST } \\
0.15 \% 1080 \\
\text { carrot }\end{array}$ & $\begin{array}{l}0.08 \\
0.08\end{array}$ & $\begin{array}{l}0 \\
0.04\end{array}$ & $\begin{array}{l}\text { Repellent baits were as palatable as standard baits. Mortality rates } \\
\text { did not differ between repellent and non-repellent baits. }\end{array}$ \\
\hline $\begin{array}{l}\text { Clapperton } \\
\text { et al. } 2015\end{array}$ & $\begin{array}{l}\text { Pen, } \\
2002-2004 \\
\text { trial } 4\end{array}$ & ST cereal & $\begin{array}{l}0.08 \\
0.08\end{array}$ & $\begin{array}{l}0 \\
0.04\end{array}$ & Repellent baits were as palatable as non-repellent baits. \\
\hline
\end{tabular}


Table 1 continued...

\begin{tabular}{|c|c|c|c|c|c|}
\hline Author & $\begin{array}{l}\text { Trial type, } \\
\text { year }\end{array}$ & Bait type & $\begin{array}{l}\text { Anthra- } \\
\text { quinone } \\
(\% \text { wt } / w t)\end{array}$ & $\begin{array}{l}\text { D-pulegone } \\
(\% \mathrm{wt} / \mathrm{wt})\end{array}$ & Summary of results \\
\hline $\begin{array}{l}\text { Clapperton } \\
\text { et al. } 2014\end{array}$ & Field, 2004 & $\begin{array}{l}\text { ST carrot, } \\
\text { then ST } \\
0.12 \% 1080 \\
\text { carrot }\end{array}$ & 0.09 & 0 & $\begin{array}{l}\text { No significant difference in the estimated reduction of possum } \\
\text { residue trap catch index between repellent treatment and the non- } \\
\text { repellent treatment. Anthraquinone and } 1080 \text { concentrations were } \\
\text { lower than nominal rates in baits sampled prior to application. }\end{array}$ \\
\hline $\begin{array}{l}\text { J Kemp } \\
\text { DOC pers. } \\
\text { comm. }\end{array}$ & Field, 2010 & $\begin{array}{l}\text { IN cereal, } \\
\text { then IN } \\
0.15 \% 1080 \\
\text { cereal }\end{array}$ & $\begin{array}{l}0 \\
0.10\end{array}$ & $\begin{array}{l}0 \text { or } 0.17 \\
\text { (prefeed), } \\
0.17 \text { (toxic) } \\
0.17 \text { (prefeed), } \\
0.17 \text { (toxic) }\end{array}$ & $\begin{array}{l}\text { No significant difference in the estimated reduction of possum } \\
\text { BMI between repellent treatments and the non-repellent } \\
\text { treatment. }\end{array}$ \\
\hline $\begin{array}{l}\text { Cowan } \\
\text { et al. } 2014\end{array}$ & Pen, 2013 & $\begin{array}{l}\text { IN cereal } \\
\text { then IN } \\
0.15 \% 1080 \\
\text { cereal }\end{array}$ & $\begin{array}{l}0 \\
0.10 \\
0.25\end{array}$ & $\begin{array}{l}0.17 \\
0.17 \\
0.17\end{array}$ & $\begin{array}{l}\text { No significant difference in palatability of prefeed baits or } \\
\text { mortality rates between these three repellent treatments and the } \\
\text { non-repellent treatment. }\end{array}$ \\
\hline $\begin{array}{l}\text { Cowan } \\
\text { et al. } 2014\end{array}$ & Pen, 2013 & $\begin{array}{l}\text { IN cereal } \\
\text { then IN } \\
0.15 \% 1080 \\
\text { cereal }\end{array}$ & $\begin{array}{l}0.25 \\
0.25 \\
\text { (prefeed } \\
\text { and toxic) }\end{array}$ & $\begin{array}{l}0 \\
0 \\
\text { (prefeed) } \\
0.17 \text { (toxic) }\end{array}$ & $\begin{array}{l}\text { Palatability of prefeed baits was lower and the amount of toxic } \\
\text { bait eaten was lower, as compared with the other repellent } \\
\text { treatments and the non-repellent treatment. These two treatments } \\
\text { had the lowest mortality rates of all treatments. }\end{array}$ \\
\hline
\end{tabular}

et al. 2011b; Table 1). There was no evidence that inclusion of $0.17 \%$ d-pulegone in baits affected bait consumption or mortality rates by wild-caught ship rats (Cowan et al. 2014). There was no evidence in previous trials that the use of up to $0.10 \% \mathrm{wt} / \mathrm{wt}$ anthraquinone and/or up to $0.17 \% \mathrm{wt} / \mathrm{wt}$ d-pulegone affected bait consumption or mortality rates for possums (Table 1). When anthraquinone was used at a higher concentration $(0.25 \% \mathrm{wt} / \mathrm{wt})$ and no d-pulegone was used in prefeed, possum consumption of prefeed and toxic baits was reduced (Cowan et al. 2014).

For the present trial, we selected two repellent treatments to test in the field: a 'primary repellent' treatment (i.e. $0.17 \%$ d-pulegone in prefeed and toxic baits) to match the Cowan et al. (2014) treatment, where rat mortality was similar to standard 1080, and a 'combined repellent' treatment (i.e. $0.17 \%$ d-pulegone and $0.10 \%$ anthraquinone in prefeed baits and $0.17 \% \mathrm{~d}$-pulegone in toxic baits) to match the strategy tested with captive kea by Orr-Walker et al. (2012) and included in a DOC field trial (J. Kemp, DOC, pers. comm.; Table 1).

The trial was designed to detect any difference between the standard (no repellent) treatment, primary repellent treatment, and the combined repellent treatment with respect to proportional reduction in possum and rat population indices, in an aerial $0.15 \% 1080 \mathrm{RS} 5$ cereal operation. All treatments were RS5 baits (Animal Control Products (ACP) Ltd, Whanganui) with $0.15 \% \mathrm{wt} / \mathrm{wt}$ cinnamon lure in prefeed baits $(16-\mathrm{mm}$ diameter) and $0.3 \% \mathrm{wt} / \mathrm{wt}$ cinnamon lure in toxic $0.15 \% 1080$ baits (20-mm diameter). Consistent with DOC current agreed best practice, the rate of application was $1 \mathrm{~kg} \mathrm{ha}^{-1}$ for prefeed and $2 \mathrm{~kg} \mathrm{ha}^{-1}$ for toxic baits for all treatments.

The three treatments were:

- Standard (no repellent): Undyed RS5 prefeed baits and green $0.15 \% 1080$ RS5 baits

- Primary repellent: $0.17 \%(\mathrm{wt} / \mathrm{wt}) \mathrm{d}$-pulegone in green RS5 prefeed baits and $0.17 \%(\mathrm{wt} / \mathrm{wt}) \mathrm{d}$-pulegone in green $0.15 \% 1080$ RS5 baits

- Combined repellent: $0.17 \%(\mathrm{wt} / \mathrm{wt}) \mathrm{d}$-pulegone and $0.10 \%$ anthraquinone in green RS5 prefeed baits and $0.17 \%$ (wt/ wt) d-pulegone in green $0.15 \%$ RS5 1080 baits

The stated repellent concentrations were the target concentrations. Higher nominal concentrations of d-pulegone were used to account for loss in manufacture and dissipation in storage (as explained in Methods below).

\section{Methods}

\section{Trial site}

Repellents were added to baits that were dropped on selected treatment blocks within a larger aerial 1080 operation (29 327 ha) conducted in November 2013 in beech-podocarp forest in an area spanning the Moeraki, Whakapohai, and Mataketake valleys near Haast on the West Coast of the South Island of New Zealand (Fig. 1). The trial treatment blocks were located in the Mataketake only. Possums and rats were monitored in the treatment and control (standard 1080 bait application) blocks at Mataketake before and after the operation, in order to detect any differences in the proportional reduction in pests between blocks. If there was no difference, this would indicate that the use of repellents was unlikely to adversely affect possum and rat kills.

The main aim of the operation was to protect scarlet mistletoe (Peraxilla colensoi) and tree fuschia (Fuchsia excorticata) from possum browsing. In the nearby Whakapohai Valley (Fig. 1), kākā (Nestor meridionalis) and ship rats are monitored as part of a research programme aimed at developing cost-effective rat control strategies to protect kākā and other birds (G. Elliot, DOC, pers. comm.). Previous aerial 1080 cereal operations took place at Moeraki, Whakapohai, and Mataketake in 2010 and 2007; earlier separate operations took place at Whakapohai (2003) and Moeraki (2004, 2000, and 1998).

As part of long-term monitoring for these three areas, possum numbers were monitored using residual trap catch index (RTCI) from November to December in 2012. The mean RTCI (and 95\% confidence interval) for Mataketake was $8.2 \% \pm 3.4$ (M. Martini, unpubl. data). Rats were not monitored in Mataketake prior to the trial; however, tracking tunnels were monitored at Whakapohai in May 2013 and their tracking index of relative abundance was approximately $42 \%$ (G. Elliot, pers. comm.). 


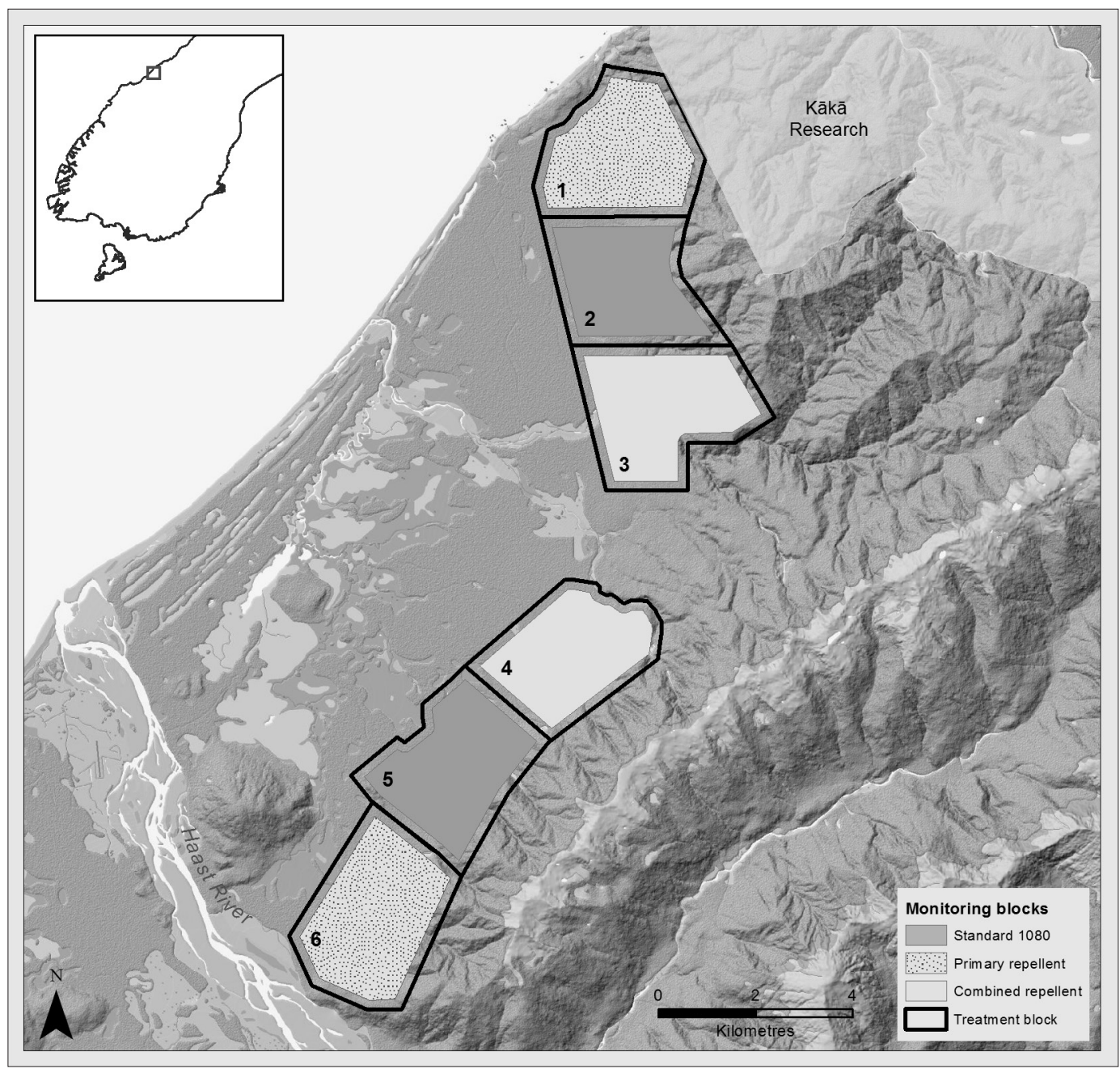

Figure 1. Location of treatment blocks and the associated monitoring blocks in an aerial 1080 cereal operation where bird repellents were used at Mataketake, near Haast on the West Coast of the South Island of New Zealand. Ship rats (Rattus rattus) were monitored using the tracking index of relative abundance and possums (Trichosurus vulpecula) were monitored using the 3-night bite mark index (BMI). Eight transects of tracking tunnels and eleven transects of WaxTags ${ }^{\circledR}$ were monitored in each block.

\section{Trial design}

There were two replicates of each treatment, located as two sets of three blocks (Fig. 1). Each block consisted of a treatment block (mean size 840 ha, shown with bold borders on Fig. 1) where particular bait treatments were applied aerially and an inner monitoring block (mean size 610 ha, shown with shading on Fig. 1) where pests were monitored and population indices estimated. We located the treatment blocks systematically. Starting with an operational map, we excluded areas that could not be monitored (too wet or too steep), areas above $500 \mathrm{~m}$ elevation (where the rat population was expected to be too low), and the Whakapohai Valley (where the kākā research was being conducted). The remaining area was all within the Mataketake and was naturally divided into two separate areas. Each of these areas was then divided into three treatment blocks. The three treatments were assigned randomly using an online die application. An internal buffer of $200 \mathrm{~m}$ was applied to each treatment block using geospatial tools, to define the inner monitoring block. The 200-m buffer was to ensure the independence of treatments, assuming that monitoring occurred 2-4 weeks after the operation. Based on the home ranges of possums and rats (Cowan 2005; Innes
2005), we expected that this distance would be sufficient to achieve negligible migration between the three blocks, or from surrounding areas between pre-operational and postoperational monitoring. Flight lines were parallel, with an additional perimeter swathe to avoid any unsown areas at the edge of each treatment block.

\section{Bait manufacture and analysis}

D-pulegone 90\% (CAS 89-82-7, 90\% active ingredient) was imported by Connell Brothers Ltd from the Penta Manufacturing Company (Livingston New Jersey, USA). Anthraquinone (Avipel Dry ${ }^{\circledR}$ CAS-84-64-1, 95\% active ingredient) was imported by Etec Crop Solutions Ltd from Arkion Life Sciences LLC (New Castle, DE, USA).

All repellent prefeed and toxic baits were manufactured by ACP. Repellents were added after the base ingredients for RS5 baits had been combined in the ACP factory mixer, at the same time the cinnamon lure, green dye, and 1080 (where applicable) were added. After further mixing, the blended ingredients were treated with steam to lubricate the dye and improve pellet cohesion, and were then immediately passed through a high-pressure radial pellet press. Formed baits were 
then passed through a cooler and a screener to remove dust and fragments, before being dispensed into approved multi-wall paper bags that contain $25 \mathrm{~kg}$ of bait.

Crowell et al. (2015) describe work to monitor the stability of repellents and 1080 in RS5 cereal baits. Some d-pulegone (22-48\% of the nominal target concentration, based on 9 batches) was lost in the manufacturing process and more dissipates over time during storage. We defined our target operational repellent concentration as $0.17 \pm 0.05 \%$ (i.e. $0.12-0.22 \%$ ), to ensure that concentrations were not too high (i.e. $>0.22 \%$ ) after 4 weeks (as we did not know whether pests would be repelled, based on the literature) or too low (i.e. $<0.12 \%$ ) after 12 weeks (as we did not know whether kea would be repelled, at a level much lower than tested with kea by Orr-Walker et al. 2012). We anticipated a storage period of 4-12 weeks and expected prefeed baits to be used 1-2 weeks sooner than toxic baits. We were guided by stability monitoring of previous batches of bait and chose nominal concentrations of $0.25 \%$ and $0.29 \%$ d-pulegone in prefeed and toxic baits, respectively (Crowell et al. 2015).

Three bags each of combined repellent prefeed baits and repellent 1080 baits were stored in conditions recommended by the manufacturer. The d-pulegone and anthraquinone concentrations in the combined repellent prefeed were assayed for both repellents on receipt (6 days after manufacture) and on the day after the prefeed baits were applied. Likewise, the repellent 1080 baits were assayed for d-pulegone and 1080 on receipt ( 2 days after manufacture) and for d-pulegone on the day that toxic baits were applied. No baits were collected from the field for repellent or 1080 assay.

\section{Monitoring design}

\section{Rats}

We used the tracking index of relative abundance as the population index for rats and followed the DOC tracking tunnel guide (Gillies \& Williams 2013). The design of our tracking tunnels varied from the design in the DOC protocol in that our corflute tunnels were triangular in profile rather than square. Using the tracking tunnel as the sampling unit, we determined that if we monitored eight transects in each block we would be able to detect a $6 \%$ difference in the post-operational tracking index between standard and repellent blocks, with power of $80 \%$ and a significance level of $\alpha=0.05$.

To locate transects, 20 random start points were generated for each monitoring block using geospatial tools. Starting with the first numbered point, a 450-m transect was fitted in an easterly direction $\left(90^{\circ}\right.$, or $270^{\circ}$ to the west if an easterly direction was not possible). A transect was deleted if it was too close to a previously accepted transect or could not be monitored safely. This process was iterated until 11 transects had been defined. Three of the eleven transects were then selected randomly and assigned as shorter $(200 \mathrm{~m})$ transects for possum monitoring only (see 'Possums' below).

Tunnels were established and baited with peanut butter on the planned transects from 17 to 22 September 2013, about 6 weeks before the pre-operational monitoring. One planned shorter transect of WaxTags ${ }^{\circledR}$ was accidentally set up with tracking tunnels, so another planned tracking tunnel transect was changed to WaxTags ${ }^{\circledR}$.

\section{Possums}

We used the three-night Bite Mark Index (BMI) as the population index for possums and followed the National
Possum Control Agencies (NPCA) protocol (NPCA 2010). This protocol requires a minimum of 11 transects of WaxTag ${ }^{\circledR}$ devices for blocks 500-800 ha in size. Using the WaxTag ${ }^{\circledR}$ as the sampling unit, this level would allow us to detect a $4 \%$ difference in the post-operational BMI between standard and repellent blocks, with power of $80 \%$ and a significance level of $\alpha=0.05$.

In each block, eight of the eleven transects were located on the first $200 \mathrm{~m}$ of the rat monitoring transects and the other three were separate shorter transects.

\section{Monitoring assessment}

Amixed effects logistic regression was applied to the data within the Bayesian framework. The fixed effects were treatment and status (i.e. pre-operational index versus post-operational index) and the response variable was the number of devices on each transect with rat tracks or possum bites. A vague normal prior distribution $\mathrm{N}\left(0,10^{2}\right)$ was assigned to the fixed effects. Additive independent, identically distributed random effects were assumed for block, transect line, and tunnel location (rats only). All the models were fitted using the WinBUGS software (Lunn et al. 2000). A chain of 100000 iterations was run after a burn-in of 5000, and every 10 th iteration was recorded, producing a sample size of 10000 from the posterior distribution. The convergence was assessed visually.

Posterior means and credible intervals (a Bayesian counterpart to confidence intervals) were estimated for the probabilities of observing rats or possums before and after each of the three treatments, as well as the respective odds ratios (ORs). Given the two probabilities $p_{0}$ and $p_{1}$ of observing a rat track or a possum bite mark before and after the treatment, respectively, the odds ratio is evaluated as:

$$
O R=\frac{\frac{p_{1}}{1-p_{1}}}{\frac{p_{0}}{1-p_{0}}}
$$

An OR less than 1 indicates that the treatment was effective in reducing the number of rat tracks or possum bites. When comparing any two treatments, the one with the lower OR is the more effective treatment.

In the Bayesian framework, the weight of evidence in favour of a certain statement is assessed in terms of posterior probability rather than statistical significance and $p$-values. Thus, the posterior probability of the OR being less than 1 $(\mathrm{P}(\mathrm{OR})<1 \mid$ data) corresponds to the weight of evidence (i.e. the observed data) in favour of the treatment being effective. The closer $(\mathrm{P}(\mathrm{OR})<1 \mid$ data $)$ is to 1 , the more evidence there is for effectiveness.

In order to test whether effectiveness in reducing the tracking index and BMI varied between the treatments, we fitted three models:

- M1, where all the treatments were forced to have the same effectiveness

- M2, where the effectiveness was allowed to vary between treatments

- M3, where the effectiveness was allowed to vary between treatments as well as between blocks (random effects).

The three models were then compared using the Deviance Information Criterion (DIC) (Spiegelhalter et al. 2002). DIC is a Bayesian measure of model fit and complexity, similar to the classical Akaike Information Criterion (AIC). The smaller the DIC is, the better is the model. Commonly, a difference of 5-10 between DIC measures is considered suggestive and 
a difference of 10 definitive (http://www.mrc-bsu.cam.ac.uk/ bugs/winbugs/dicpage.shtml\#q9). Where applicable, ORs were compared between treatments to evaluate their relative efficiency at reducing the tracking index or BMI.

The possible presence of spatial autocorrelation in the tunnel- and line-specific random effects was investigated by estimating Moran's I. Moran's I is a common measure of spatial autocorrelation (Moran 1950), taking values from -1 (perfect negative autocorrelation) to 1 (perfect positive autocorrelation). The value of 0 corresponds to spatial independence.

\section{Results}

\section{Bait manufacture and analysis}

Standard prefeed and 1080 baits were manufactured on 30 October 2013. Both batches of repellent prefeed were manufactured on 1 November, and the batch of repellent 1080 bait was manufactured on 5 November.

The d-pulegone concentration in the combined repellent prefeed baits was $0.14 \%$ on receipt ( 6 days after manufacture) and $0.14 \%$ on the day after prefeed was applied (11 days after manufacture). The anthraquinone concentration was $0.09 \%$ on receipt; because this was less than expected, we re-sampled on the day after prefeed was applied and obtained a similar result $(0.08 \%)$. This means that repellent baits contained the target operational concentration of d-pulegone when prefeed was applied and the anthraquinone was very close to the target operational concentration $(0.10 \%)$.

The d-pulegone concentration in the repellent 1080 baits was $0.21 \%$ and the 1080 concentration was $0.13 \%$ on receipt (2 days after manufacture). Baits contained the target operational concentration when aerially applied, as the d-pulegone concentration in stored baits was $0.15 \%$ on the first day toxic baits were sown (17 days after manufacture).

\section{Trial execution}

Prefeed baits were applied on 11 November 2013 and the toxic baits were applied in block 6 and most of block 4 on 22
November (11 days after prefeed) and in all remaining blocks on 23 November (12 days after prefeed). Flight lines were checked on sites for even coverage and perimeter sowing. Fine weather conditions prevailed on all days that baits were sown and for the nights from 22 through to 28 November. There were light showers during the day on the 25 November ( $25 \mathrm{~mm}$ between 0600 and 1700), followed by fine weather through to the afternoon of 29 November.

\section{Monitoring execution}

Pre-operational monitoring took place 7-10 days before the aerial application of prefeed baits. Tracking cards were placed in tunnels on either 31 October or 2 November; weather was fine or overcast overnight and tracking cards were collected the following day. WaxTags ${ }^{\circledR}$ were placed at the same time as tracking cards were collected; these devices were collected after 3 nights. Weather was fine or overcast for the 3 nights (other than a short period of rain in the early evening of 31 October).

Post-operational monitoring commenced on 5 December, 13-14 days after toxic baits were applied. Tracking cards were placed in tunnels on either 5 or 10 December and collected the following day. WaxTags ${ }^{\circledR}$ were placed in blocks $1-3$ on 6 December and in blocks 4-6 on 9 December; these devices were collected after 3 nights. There were rain showers for periods on the nights of 5, 7,9 and 10 December, but weather was clear well before dawn on all days.

\section{Monitoring assessment}

A summary of mean pre- and post-operational monitoring indices and proportional reductions observed for each trial block is listed in Table 2 and presented in a graph in Fig. 2.

\section{Rats}

The tracking index was reduced by $100 \%$ in both the standard treatment blocks, by $100 \%$ and $96 \%$ in the primary repellent treatment blocks, and by $89 \%$ and $78 \%$ in the combined repellent treatment blocks. The mean post-operational tracking indices for rats in the combined repellent treatment blocks were $3 \% \pm 2$ (standard error) and $8 \% \pm 6$.

Table 2. Summary of pest monitoring at trial blocks in an aerial 1080 cereal operation where bird repellents were used at Mataketake, near Haast on the West Coast of the South Island of New Zealand. Mean tracking index for ship rats (Rattus rattus) and 3-night bite mark index (BMI) for possums (Trichosurus vulpecula) are reported by trial block, as well as the proportional reduction in the mean indices. Eight transects of tracking tunnels and eleven transects of WaxTags ${ }^{\circledR}$ were monitored in each block. Block numbers correspond to those shown on the map in Figure 1. Prefeed and 1080 baits sown on the standard blocks contained no repellents, and those sown in the primary repellent blocks contained d-pulegone. Prefeed baits in the combined repellent blocks contained both d-pulegone and anthraquinone whereas the toxic baits were the same as those in the primary repellent blocks.

\begin{tabular}{lllllll}
\hline Block & $\begin{array}{l}\text { Mean pre- } \\
\text { operational } \\
\text { tracking index } \\
\text { for rats (\%) }\end{array}$ & $\begin{array}{l}\text { Mean post- } \\
\text { operational } \\
\text { tracking index } \\
\text { for rats (\%) }\end{array}$ & $\begin{array}{l}\text { Proportional } \\
\text { reduction of } \\
\text { tracking index } \\
\text { for rats (\%) }\end{array}$ & $\begin{array}{l}\text { Mean pre- } \\
\text { operational } \\
\text { BMI for } \\
\text { possums (\%) }\end{array}$ & $\begin{array}{l}\text { Mean post- } \\
\text { operational } \\
\text { BMI for } \\
\text { possums (\%) }\end{array}$ & $\begin{array}{l}\text { Proportional } \\
\text { reduction of } \\
\text { BMI for } \\
\text { possums (\%) }\end{array}$ \\
\hline 1 Primary repellent & $14 \pm 5$ & $0 \pm 0$ & 100 & $6.1 \pm 1.8$ & $3.8 \pm 2.3$ & 38 \\
2 Standard & $35 \pm 6$ & $0 \pm 0$ & 100 & $8.6 \pm 4.0$ & $1.8 \pm 1.8$ & 79 \\
3 Combined repellent & $28 \pm 9$ & $3 \pm 2$ & 89 & $2.2 \pm 1.2$ & $0.5 \pm 0.5$ & 77 \\
4 Combined repellent & $36 \pm 7$ & $8 \pm 6$ & 78 & $34.5 \pm 10.0$ & $4.1 \pm 2.0$ & 88 \\
5 Standard & $24 \pm 6$ & $0 \pm 0$ & 100 & $30.5 \pm 8.6$ & $5.5 \pm 2.8$ & 82 \\
6 Primary repellent & $28 \pm 6$ & $1 \pm 1$ & 96 & $23.6 \pm 5.8$ & $1.4 \pm 0.7$ & 94 \\
\hline
\end{tabular}




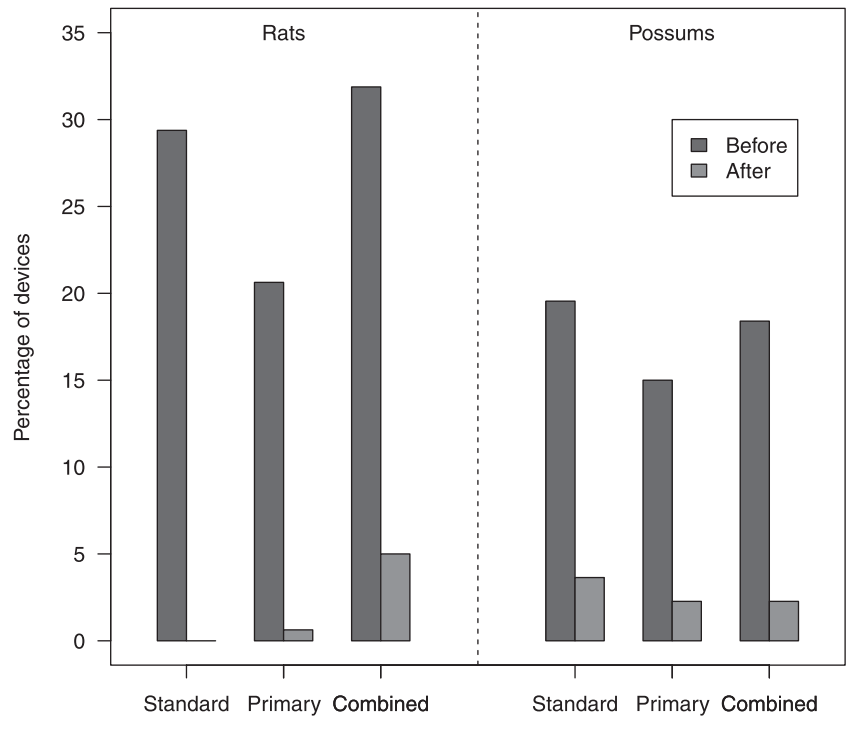

Figure 2. Proportion of tunnels tracked by ship rats (Rattus rattus) and WaxTags ${ }^{\circledR}$ bitten by possums (Trichosurus vulpecula) before and after standard treatment, primary repellent treatment, and combined repellent treatment in an aerial 1080 cereal operation where bird repellents were used at Mataketake, near Haast on the West Coast of the South Island of New Zealand. Prefeed and 1080 baits sown on the standard blocks contained no repellents, and those sown in the primary repellent blocks contained d-pulegone. Prefeed baits in the combined repellent blocks contained both d-pulegone and anthraquinone and the toxic baits were the same as in the primary repellent blocks.

The DICs calculated for the three models were as follows:

- M1 (there was no difference in efficacy between treatments), $\mathrm{DIC}=621.077$

- M2 (there were differences in efficacy between treatments), $\mathrm{DIC}=616.209$

- M3 (random block effects contributed to the differences in efficacy between treatments), DIC $=616.652$

The difference of 4.868 between the DICs for M1 and M2 suggests that M2 is a statistically better model than M1. The corresponding difference of 0.443 between M2 and M3 indicates that the treatment efficacy did not vary between blocks. For the best model, M2, the posterior mean estimated proportion of tunnels that were tracked before and after treatment and the corresponding OR for each treatment are shown in Table 3.

The posterior mean OR was much less than 1 for every treatment, indicating that all treatments were effective at reducing the tracking index. Pairwise comparisons of the ORs (Table 4, Fig. 3) indicated that the standard treatment was more effective at reducing the tracking rate than either repellent treatment, and the primary repellent treatment was more effective than the combined repellent treatment.

We found no evidence of spatial autocorrelation among the estimated tunnel-specific random effects. The mean Moran's I was -0.0005 , with a $95 \%$ credible interval of -0.0200 to 0.0209 . The proportion of WaxTags ${ }^{\circledR}$ bitten by rats in the possum monitoring was also analysed for differences between treatment blocks, with similar results.

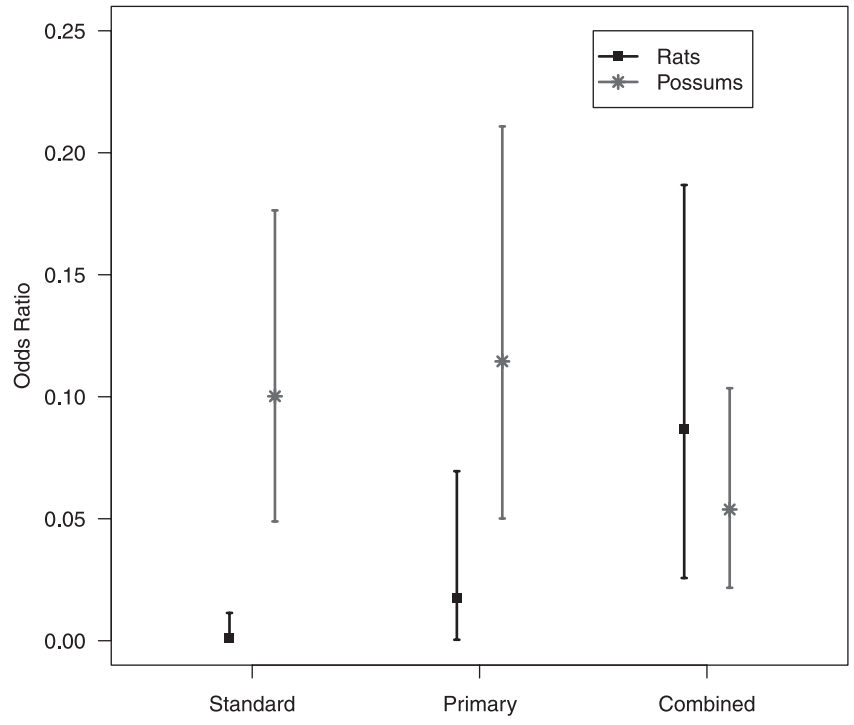

Figure 3. Posterior mean odds ratios and $95 \%$ credible intervals for the changes in proportion of tunnels tracked by rats (Rattus rattus) and WaxTags ${ }^{\circledR}$ bitten by possums (Trichosurus vulpecula) the standard treatment, primary repellent treatment, and combined repellent treatment in an aerial 1080 cereal operation where bird repellents were used at Mataketake, near Haast on the West Coast of the South Island of New Zealand. Prefeed and 1080 baits sown on the standard blocks contained no repellents, and those sown in the primary repellent blocks contained d-pulegone. Prefeed baits in the combined repellent blocks contained both d-pulegone and anthraquinone and the toxic baits were the same as in the primary repellent blocks.

\section{Possums}

The BMI was reduced by $79 \%$ and $82 \%$ in the standard treatment blocks, by $38 \%$ and $94 \%$ in the primary repellent treatment blocks, and by $77 \%$ and $88 \%$ in the combined repellent treatment blocks. The mean post-operational BMI was $1.8 \%$ and $5.5 \%$ in the standard treatment blocks, $3.8 \%$ and $1.4 \%$ in the primary treatment blocks, and $0.5 \%$ and $4.1 \%$ in the combined treatment blocks.

The results were modelled to estimate the posterior mean estimated proportion of WaxTags ${ }^{\circledR}$ that were bitten before and after treatment and the odds ratio for each treatment was estimated (Table 3). The DIC was calculated for the model under the first two hypotheses: M1 - where there was no difference in efficacy between treatments (DIC $=384.957$ ); and M2 - where there were differences in efficacy between treatments $(\mathrm{DIC}=385.548)$. The difference of 0.591 between the two DIC calculations suggests that there is no statistical evidence of difference in the efficacy of the three treatments, and on this basis we did not look for random variation between blocks (M3).

The posterior mean OR was much less than 1 for every treatment, indicating that all treatments were effective at reducing the BMI. No pairwise differences were found (Fig. 3).

The random effect of transect location was investigated and we found no evidence of spatial autocorrelation. The mean Moran's I was -0.0266 , with a $95 \%$ credible interval of -0.0711 to 0.0543 . 
Table 3. Results from the mixed effects logistic regression applied to the proportion of monitoring devices marked by pests in an aerial 1080 cereal operation where bird repellents were used at Mataketake, near Haast on the West Coast of the South Island of New Zealand. Prefeed and 1080 baits sown on the standard blocks contained no repellents, and those sown in the primary repellent blocks contained d-pulegone. Prefeed baits in the combined repellent blocks contained both d-pulegone and anthraquinone and the toxic baits were the same as in the primary repellent blocks. The proportion of tracking tunnels tracked by ship rats (Rattus rattus) is reported in the upper half of the table and the proportion of WaxTags ${ }^{\circledR}$ bitten by possums (Trichosurus vulpecula) is reported in the lower half of the table. The posterior means and estimates of the odds ratios (ORs) were estimated by the model within a Bayesian framework. The last column reports the probability of the OR being less than 1 (i.e. treatment was effective in lowering the rat tracking index) given the data we observed.

\begin{tabular}{|c|c|c|c|c|c|c|c|c|}
\hline Treatment & $\begin{array}{l}\text { Observed } \\
\text { proportion } \\
\text { before } \\
\text { treatment }\end{array}$ & $\begin{array}{l}\text { Observed } \\
\text { proportion } \\
\text { after } \\
\text { treatment }\end{array}$ & $\begin{array}{l}\text { Posterior } \\
\text { mean } \\
\text { estimated } \\
\text { proportion } \\
\text { before } \\
\text { treatment }\end{array}$ & $\begin{array}{l}\text { Posterior } \\
\text { mean } \\
\text { estimated } \\
\text { proportion } \\
\text { after } \\
\text { treatment }\end{array}$ & $\begin{array}{l}\text { Posterior } \\
\text { mean } \\
\text { estimated } \\
\text { OR }\end{array}$ & $\begin{array}{l}\text { Lower } \\
\text { bound of } \\
95 \% \text { credible } \\
\text { interval for } \\
\text { OR }\end{array}$ & $\begin{array}{l}\text { Upper } \\
\text { bound of } \\
95 \% \text { credible } \\
\text { interval for } \\
\text { OR }\end{array}$ & $\begin{array}{l}\mathrm{P}(\mathrm{OR}<1 \\
\mid \text { data })\end{array}$ \\
\hline
\end{tabular}

\begin{tabular}{|c|c|c|c|c|c|c|c|c|}
\hline \multicolumn{9}{|c|}{ Proportion of tunnels tracked by rats } \\
\hline Standard & 0.2938 & 0.0000 & 0.2274 & 0.0004 & 0.0013 & 0.0000 & 0.0114 & $>0.9999$ \\
\hline Primary repellent & 0.2063 & 0.0063 & 0.2274 & 0.0053 & 0.0176 & 0.0004 & 0.0694 & $>0.9999$ \\
\hline Combined repellent & 0.3188 & 0.0500 & 0.2274 & 0.0255 & 0.0866 & 0.0257 & 0.1868 & $>0.9999$ \\
\hline \multicolumn{9}{|c|}{ Proportion of WaxTags ${ }^{\circledR}$ bitten by possums } \\
\hline Standard & 0.1955 & 0.0364 & 0.1032 & 0.0130 & 0.1002 & 0.0489 & 0.1764 & $>0.9999$ \\
\hline Primary repellent & 0.1500 & 0.0227 & 0.1032 & 0.0148 & 0.1145 & 0.0501 & 0.2108 & $>0.9999$ \\
\hline Combined repellent & 0.1840 & 0.0227 & 0.1032 & 0.0073 & 0.0538 & 0.0217 & 0.1035 & $>0.9999$ \\
\hline
\end{tabular}

Table 4. Pairwise comparisons of the odds ratios (ORs) observed for ship rat (Rattus rattus) tracking in the standard treatment $(\mathrm{S})$, primary repellent treatment $(\mathrm{P})$, and combined repellent treatment $(\mathrm{C})$ in an aerial 1080 cereal operation where bird repellents were used at Mataketake, near Haast on the West Coast of the South Island of New Zealand. Prefeed and 1080 baits sown on the standard blocks contained no repellents, and those sown in the primary repellent blocks contained d-pulegone. Prefeed baits in the combined repellent blocks contained both d-pulegone and anthraquinone and the toxic baits were the same as in the primary repellent blocks. When comparing any two treatments, the one with the lower OR is the more effective at reducing the proportion of tunnels tracked by rats than the other treatment. The closer the posterior probability is to 1 , the higher the weight of statistical evidence in favour of the hypothesis.

\begin{tabular}{lll}
\hline Comparison & Posterior probability & Interpretation \\
\hline OR (P) > OR (S) & 0.9431 & The standard treatment is, on average, more effective than the primary treatment. \\
OR (C) > OR (P) & 0.9714 & The primary treatment is, on average, more effective than the combined treatment. \\
OR (C) > OR (S) & 0.9999 & The standard treatment is, on average, more effective than the combined treatment. \\
\hline
\end{tabular}

\section{Discussion}

\section{Bait manufacture and analysis}

Fortunately, the operation occurred soon after bait manufacture and both the prefeed and toxic baits met the target operational d-pulegone concentration of $0.17 \pm 0.05 \%$. The prefeed baits contained about $0.14 \%$ d-pulegone when sown 10 days after manufacture and the toxic baits contained about $0.15 \%$ d-pulegone when sown 17-18 days after manufacture. Stored bags of prefeed and toxic baits continued to be sampled and analysed as part of the bait stability study reported by Crowell et al. (2015). This showed that the both the prefeed and toxic baits dropped below their target operational concentrations shortly after the operation, despite being manufactured at nominal concentrations of $0.25 \%$ and $0.29 \%$ d-pulegone, respectively. Stored prefeed baits contained $0.09 \%$ d-pulegone 3 weeks after manufacture and toxic baits contained $0.11 \%$ d-pulegone 4 weeks after manufacture. Since most 1080 aerial cereal operations typically occur 4-12 weeks after manufacture (T. Farrell, DOC, and M. Hickson, TBfree New Zealand, pers. comms), this high rate of dissipation would compromise the effectiveness of this repellent. We would struggle to achieve the target operational concentration of d-pulegone with current production methods, given that few pest control operations occur as soon after manufacture as this trial, and that the dissipation of d-pulegone has been highly variable across monitored batches (Crowell et al. 2015).

The anthraquinone concentration was about $0.08 \%$ in the prefeed baits, which was slightly lower than the nominal concentration of $0.10 \%$. We believe that this level was close enough to the nominal concentration to provide meaningful trial results.

\section{Rats}

There was a statistically significant difference in the proportional reduction in rat abundance achieved between treatments. The standard treatment reduced the rat tracking index more effectively than either repellent treatment. The difference between the standard and primary repellent treatment is somewhat surprising, given that acceptability, palatability, and mortality did not differ between rats in the standard treatment and the primary repellent treatment with the same 
type of baits in a DOC field trial (J. Kemp, pers. comm.) and the Cowan et al. (2014) pen trial. Clapperton et al. (2015) also found no difference in palatability to laboratory rats between carrot baits surface treated with d-pulegone and non-repellent carrot baits. However, interpretation of the results needs to take into account the limitations of the tracking index, which is a relatively coarse index of relative abundance (Gillies 2013). Gillies (DOC, pers. comm.) cautions that results should be interpreted broadly in classes such as not detected $(0 \%)$, low abundance (e.g. $<5 \%$ ), normal abundance (situation dependent), and high abundance. All the standard and primary repellent blocks had mean post-operational tracking indices of either $0 \% \pm 0$ or $1 \% \pm 1$, so any difference in indices is unlikely to reflect a real difference in rat abundance.

The combined repellent treatment reduced the rat tracking index less effectively than either the standard or primary repellent treatment. This is consistent with the observations of Cowan et al. (2014), where mortality was significantly lower in all treatments where anthraquinone was included in baits compared with those using either the standard or primary repellent treatment. This difference was not detected in the DOC field trial (J. Kemp, pers. comm.), although a relatively low percentage reduction of rodent abundance was noted in the combined repellent treatment. In the Clapperton et al. (2015) 2002-2004 pen trials with rats, mortality rates did not differ between repellent (anthraquinone, 0.04-0.08\% wt/wt and d-pulegone $0-0.04 \% \mathrm{wt} / \mathrm{wt}$ ) and non-repellent treatment in trials 1 and 3 . However, mortality rates were significantly lower (no more than $20 \%$ kill rate) in the repellent treatment for trial 2.

Effective rat control is critical for aerial 1080 operations aiming to protect a range of biodiversity values, with a target of $<5 \%$ rat tracking index considered sufficient to protect native animals from rat predation. On one of the combined repellent blocks rats were suppressed to this level $(3 \% \pm 2)$ but not on the other $(8 \% \pm 6)$. The level of rat suppression may, however, be adequate to reduce stoat numbers through the aerial application of 1080 , which relies on poisoned rats acting as vectors for the secondary poisoning of stoats (Murphy et al. 1999). Nonetheless, this trial indicates that the combined repellent treatment falls short of the project criterion that ship rat kills remain high.

We considered whether the concentration of anthraquinone could be reduced in this treatment to a level where rat kills would be unaffected, bearing in mind that Werner et al. (2011b) found the degree of repellency for black-tailed prairie dogs was not directly related to anthraquinone concentration in the range of $0.5-4 \%\left(\mathrm{r}^{2}=0.210, P=0.438\right.$; see Table 1$)$. Other birds in New Zealand were repelled by surface-applied anthraquinone at lower concentrations. North Island robins reduced their consumption of dough baits treated with $0.045 \%$ $\mathrm{wt} / \mathrm{wt}$ anthraquinone (nominal concentration) and either cinnamon or d-pulegone (Clapperton et al. 2014). Some of the effective repellent treatments tested on wheat with house sparrows had nominal concentrations as low as 0.03 or $0.04 \%$ $\mathrm{wt} / \mathrm{wt}$ anthraquinone with scent or visual cues (Clapperton et al. 2012; Day et al. 2012). In a field trial by Clapperton et al. (2014), tomtit abundance increased significantly more in a block treated with carrot baits surface-treated with $0.057 \% \mathrm{wt} / \mathrm{wt}$ anthraquinone in prefeed and $0.045 \% \mathrm{wt} / \mathrm{wt}$ anthraquinone in toxic baits (analysed concentrations) than in the block treated with non-repellent bait.

Since then, DOC (Reardon 2014) carried out an aviary trial in which kea were fed undyed RS5 prefeed cereal baits containing $0.14 \%$ anthraquinone for 4 days and $1.75 \%$ anthraquinone for 3 days (analysed concentrations). While some kea reduced their consumption of bait over the course of one or both of these repellent sessions, bait consumption was still too high to rule out potential poisoning of most birds if the baits had been toxic. This suggests that a lowered anthraquinone concentration would be unlikely to prevent kea poisoning.

\section{Possums}

There was no evidence of any statistically significant difference in the proportional reduction in WaxTags ${ }^{\circledR}$ bitten by possums between the three treatments. This suggests that the repellents do not reduce possum kills relative to standard aerial 1080 cereal. This result is consistent with those obtained in pen trials by Cowan et al. (2014), who found that, with the exception of two treatments not represented in this field trial, measures of palatability and mortality did not differ between treatments. Similarly, pen trials by Clapperton et al. (2015) did not find any differences in palatability or mortality rates for possums in their pen trials. Our results are also consistent with field trials with similar treatments (Kemp 2010; Clapperton et al. 2014) and suggest that either the primary repellent or combined repellent treatment could be used in possum control operations without adversely affecting the reduction of possums.

\section{Conclusions}

The primary repellent achieved proportional reductions in both the possum and rat population indices, to a sufficiently low level to protect species threatened by these pests. In order to be used operationally, we need to find a way to stabilise d-pulegone in cereal baits for 4-12 weeks after bait manufacture to allow for the storage of baits before aerial operations (Crowell et al. 2015).

We are less optimistic about reducing the anthraquinone concentration in the combined repellent treatment to a level where rat kills would remain high, given that rodent repellency may not be directly related to concentration (Werner et al. 2011b) and, when focussing on kea protection, captive birds still consumed cereal pellets containing $0.14 \%$ anthraquinone (Reardon 2014).

Until improved methods for incorporating d-pulegone into cereal baits are developed, we recommend investigation of the alternative repellents identified by Cowan et al. (2015), namely tannic acid, ortho-aminoacetophenone, and garlic oil. Initial testing should focus on screening against possums and rats, rather than with kea. Our opportunities to test repellents with kea and other threatened birds are limited, whether in captivity or in the wild, making it imperative to reserve these opportunities for repellents that have already been tested for pest efficacy. An understanding of the pest impacts of repellents is relevant, irrespective of which threatened bird species we want to deter from consuming 1080 baits. For this reason, it is important to establish that pest mortality levels will remain high with a specific repellent strategy before screening with any threatened bird species.

\section{Acknowledgements}

This trial was part of a DOC Investigation number 4466 and was funded by DOC and TBfree New Zealand (Project 
$\mathrm{R}-80719-03)$. It was conducted under provisional registration from the Ministry for Primary Industries and under approval from the Department of Conservation Animal Ethics Committee (AEC Number 253). The Reardon (2014) report is available on request from the corresponding author.

We were fortunate to have constructive feedback on the field trial design from Phil Cowan, Peter Dilks, Terry Farrell, Alastair Fairweather, Craig Gillies, and Bruce Warburton. We are grateful to Gary Scott for managing the operation and to Julian Tovey for his work on the operation and for supplying weather data.

Ahuge team of people were involved in the monitoring. We thank Ruth Garland, Jack Mace, David Soper, Sarah Forder, Pat Crowe, Lyndon Slater, Luke Martin, Cielle Stephens, Paul Van Klink, Tony Magee, Kerry Weston, Tim Shaw, Tom Goodman, Tom Belton, Liam Anderson, Martin Abel, Emerson Wyman, Jack Grinsted, Hamish Choat, Andrew Joliffe, and Jeff Rawles for their skill and perseverance in establishing the tunnels or carrying out the monitoring. Our fantastic pilot Greg Gamble flew in the monitoring team and negotiated the weather to get them where they needed to be.

Bill Simmons led the team at Animal Control Products to manufacture all baits for the trial. Lynn Booth managed the analysis of baits for repellent and 1080 concentrations. Cielle Stephens and Robyn Crisford provided geospatial analysis and mapping. Paul Livingstone, Simon Andrew and Matthew Hickson at TBfree New Zealand are thanked for their support and advice on the trial. We thank Lynette Clelland, Ron Moorhouse and an anonymous reviewer for valuable comments on an earlier version of the manuscript.

\section{References}

Clapperton BK, Porter RER, Day TD, Waas JR, Matthews LR 2012. Designer repellents: combining olfactory, visual or taste cues with a secondary repellent to deter free-ranging house sparrows from feeding. Pest Management Science 68: 870-877.

Clapperton BK, Morgan DKJ, Day TD, Oates KE, Beath AM, Cox NR, Matthews LR 2014. Efficacy of bird repellents at deterring North Island robins (Petroica australis longipes) and tomtits (P. macrocephala toitoi) from baits. New Zealand Journal of Ecology 38: 116-123.

Clapperton BK, Day TD, Morgan DKJ, Huddart F, Cox N, Matthews LR 2015. Palatability and efficacy to possums and rats of pest control baits containing bird repellents. New Zealand Journal of Zoology doi: 10.1080/03014223.2015.1029496

Clark, L, Avery ML 2013. Effectiveness of chemical repellents in managing birds at airports. In: DeVault TL, Blackwell $\mathrm{BF}$, Belant JF eds Wildlife in airport environments: preventing animal-aircraft collisions through sciencebased management. Baltimore, MD, The Johns Hopkins University Press, in association with The Wildlife Society. Pp. 25-35.

Cowan PE 2005. Brushtail possum. In: King CM ed. The handbook of New Zealand mammals, 2nd edn. Melbourne, Oxford University Press. Pp. 56-80.

Cowan P, Brown S, Forrester G, Booth L, Crowell M 2014. Bird-repellent effects on bait efficacy for control of invasive mammal pests. Pest Management Science. doi: $10.1002 /$ ps. 3887

Cowan P, Booth L, Crowell M 2015. Repellents with potential to protect kea and other native birds from aerial poisoning for possum and rat control. New Zealand Journal of Ecology 40: 29-41.

Crowell M, Booth L, Cowan P, Fairweather A, Westbrooke I 2015. Stability of bird repellents used to protect kea (Nestor notabilis) during aerial 1080 cereal drops. New Zealand Journal of Ecology 40: 49-59.

Day TD, Matthews LR, Flight KE, Aukett MJ 2000. Low-cost bird repellents for possum baits. Unpublished report to Animal Health Board. http://www.tbfree.org.nz/lowcost-bird-repellants-for-possum-baits.aspx (accessed 18 August 2015)

Day TD, Matthews LR, Waas JR 2003. Repellents to deter New Zealand's North Island robin Petroica australis longipes from pest control baits. Biological Conservation 114: 309-316.

Day TD, Clapperton BK, Porter RER, Waas JR, Matthews LR 2012. Responses of free-ranging house sparrows to feed containing primary and secondary repellents. New Zealand Journal of Crop and Horticultural Science 40(2): 127-138.

Department of Conservation 2014. DOC code of practice for aerial 1080 in kea habitat. Wellington, Department of Conservation. http:/www.doc.govt.nz/Documents/ conservation/threats-and-impacts/pest-control/othertechnical-documents/code-of-practice-aerial-1080-keahabitat.pdf (accessed 18 August 2015)

Gillies C 2013. Animal pests: tracking tunnel indices of small mammal abundance. Wellington, Department of Conservation. http://www.doc.govt.nz/Documents/ science-and-technical/inventory-monitoring/im-toolboxanimal-pests-tracking-tunnel-indices-of-small-mammalabundance.pdf (accessed 18 August 2015)

Gillies C, Williams D 2013. DOC tracking tunnel guide v 2.5.2: using tracking tunnels to monitor rodents and mustelids. Wellington, Department of Conservation. http:// www.doc.govt.nz/Documents/science-and-technical/ inventory-monitoring/im-toolbox-animal-pests-usingtracking-tunnels-to-monitor-rodents-and-mustelids.pdf (accessed 18 August 2015)

Innes JG 2005. Ship rat. In: King CM ed. The handbook of New Zealand mammals, 2nd edn. Melbourne, Oxford University Press. Pp. 187-203.

Lunn DJ, Thomas A, Best N, Spiegelhalter D 2000. WinBUGS - a Bayesian modelling framework: concepts, structure, and extensibility. Statistics and Computing 10: 325-337.

Moran P 1950. Notes on continuous stochastic phenomena. Biometrika 37: 17-23.

Murphy EC, Robbins L, Young JB, Dowding JE 1999. Secondary poisoning of stoats after an aerial 1080 poison operation in Pureora forest, New Zealand. New Zealand Journal of Ecology 23: 175-182.

National Possum Control Agencies 2010. Possum population monitoring using the WaxTag ${ }^{\circledR}$ method. Wellington, National Possum Control Agencies. 18 p.

Orr-Walker T, Adams NJ, Roberts LG, Kemp JR, Spurr EB 2012. Effectiveness of the bird repellents anthraquinone and d-pulegone on an endemic New Zealand parrot, the kea. Applied Animal Behaviour Science 137: 80-85.

Parkes J, Murphy E2003. Management of introduced mammals in New Zealand. New Zealand Journal of Zoology 30: 335-359.

Reardon J 2014. Kea repellent development report July 2014. Unpublished report to Department of Conservation. $20 \mathrm{p}$. Spiegelhalter DJ, Best NG, Carlin BP, van der Linde A 2002. 
Bayesian measures of model complexity and fit (with discussion). Journal of the Royal Statistical Society Series B 64: 583-640.

Spurr E2008. Bird(kea) repellent research. Unpublished report to the Kea Conservation Trust. 5p. Available on request from the Kea Conservation Trust www.keaconservation. co.nz (accessed 18 August 2015)

Spurr EB, Porter RER, Thomson C 2001. Palatability of bird repellents to Rattus norvegicus. Pest Management Science 57: 615-619.

Van Klink P, Crowell M 2014. Kea (Nestor notabilis) survivorship through a 1080 operation using cereal baits containing the bird repellent d-pulegone at Otira, central Westland. DOC Research \& Development Series 344. Wellington, Department of Conservation. 13 p.

Editorial board member: Kerri-Anne Edge

Received 12 November 2014; accepted 12 August 2015
Veltman CJ, Westbrooke IM 2011. Forest bird mortality and baiting practices in New Zealand aerial 1080 operations from 1986 to 2009. New Zealand Journal of Ecology 35: 21-29.

Werner SJ, Linz GM, Carlson JC, Pettit SE, Tupper SK, Santer MM 2011a. Anthraquinone-based bird repellent for sunflower crops. Applied Animal Behaviour Science 129: $162-169$.

Werner SJ, Tupper SK, Pettit SE, Carlson JC, Linz GM 2011 b. Anthraquinone repellent to reduce take of non-target birds from zinc phosphide rodenticide applications. Applied Animal Behaviour Science 135: 146-153. 